\title{
Experimental Study on Continuous RC Flat Slabs with Openings Strengthened with CFRP
}

\author{
M. S. Shoukry, T. M. Altoni, H. M. F. Elbakry, and M. S. Ibraheem
}

\begin{abstract}
Introducing openings in existing reinforced concrete slabs can severely weaken the slabs due to the cut out of both concrete and reinforcing steel which affects the overall behavior of the slab. This paper examines, experimentally, both the effect of openings either in column/field strips or in column/column strips and the effect of strengthening the opened flat slabs with sheets of Carbon Fiber Reinforced Polymers (CFRP) as a way of restoring the original load capacity of the flat slabs without openings. A total of five large scale reinforced concrete (RC) slabs were tested up to failure. It was found that the location of the opening is effective on the behavior as it affects the ductility, toughness and failure modes. Also, it was concluded that CFRP strengthening of slabs with openings affects both failure load and failure mode of slab. Due to presence of openings, the specimens showed a decrease in failure load capacity by about $25 \%$ with respect to the control slab S1. The use of CFRP enables the slabs to restore approximately its full load capacity.
\end{abstract}

Keywords - Flat Slab, Openings, Strengthening, CFRP, Continuous, Debonding.

\section{Introduction}

It is often necessary to introduce cut outs, openings in RC slabs to satisfy structural and functional changes such as stairs, elevators or utility ducts. Openings reduce the load carrying capacity, stiffness, energy and ductility of the slabs. It is important to investigate a strengthening technique to overcome the negative effects of openings in the behavior of flat slabs. During the last decade, the use of fiber reinforced polymers (CFRP) for retrofitting and strengthening became a valid alternative because of their small thickness, relative ease of application, high strength over conventional material, light weight and highly durability. Many researches were conducted to study the effect of the presence of openings and also, the behavior when theses slabs strengthened with CFRP. Many codes such as (ACI 318-14) [1], CAN-A23.3-M94 [2] and AS3600-94 [3], require no special analysis for flat slabs with opening in the following locations a) in the common areas at the intersecting of column strips if not more than one eighth of the width of column strip in either span shall be interrupted by openings.

M. S. Shoukry

Faculty of Engineering, Alexandria University Egypt

T. M. Altoni and H.M. F. Elbakry

Faculty of Engineering, Alexandria University

Egypt

M. S. Ibraheem

Higher institute for Engineering and Technology (HIET)

Egypt b) in the intersecting area between column strip and one middle strip if not more than one quarter of the length in either strip shall be interrupted by openings. Ibrahim [4] studied numerically the effect of openings near columns on the behavior of flat plates. He investigated different opening sizes at different locations from column face. He recommended avoiding using wide openings located at the column face (less than three times slab thickness) due to their significant effect on the behavior of the flat slab. It was recommended that this kind of opening should be avoided if possible. Tayel, et al [5] tested fourteen square slabs to study the effect of square and circular opening on the behavior of flat slab supported on four corners. They concluded that circular openings result in deflections less than that due to square openings. The deflection increases close to the openings, and decreases far from openings.

Sheetal and Itti [6] conducted a finite element analysis of two way reinforced concrete slab with central opening to study the effect of variation of the boundary conditions on displacement. The study showed that the slab with all edges simply supported had maximum displacement while the slab with all the edges fixed had least displacement. Tanu, et al [7] concluded that deflection of slab with circular and square openings are about $25 \%$ less when it is strengthened with CFRP. Rashied [8] concluded that the opening size, distance from the face, reinforcement ratio, compressive strength, the effective depth and the flexural reinforcement detailing have significant influence on the punching shear resistance. Enochsson, et al [9] studied the structural behavior of two-way RC slabs strengthened with CFRP due to an opening, subjected to uniformly distributed loads. The results from the tests showed that slabs with openings can be strengthened with externally bonded CFRP sheets. The slabs with the larger openings have a noticeable higher load carrying capacity and a stiffer load-deflection response than the slabs with the smaller openings. Tan [10] carried out an experimental work to investigate the use of FRP systems in restoring the ultimate strength of reinforced concrete flat slabs in which an opening has been created $(500 \times 500 \mathrm{~mm})$. Test results showed that the ultimate strength of the slab was restored to that of the solid slab when the opening was placed along the diagonal at twice the effective depth from the column stub.

In this paper, five continuous flat slabs subjected to sixteen increasing concentrated loads, in order to simulate a distributed load, were tested. There are two main objectives of this research. The first is to study the effect of openings upon the load capacity, maximum deflections and ductility. The second is to study the use of carbon fiber reinforced polymer (CFRP) strengthening to restore the load capacity of flat slabs after having openings cut out in the positive and negative moment regions. 
Proc. of the Fifth International Conference on Advances in Civil, Structural and Environmental Engineering - ACSEE 2017. Copyright (C) Institute of Research Engineers and Doctors. All rights reserved.

ISBN: 978-1-63248-122-1 doi: 10.15224/ 978-1-63248-122-1-31

\section{Experimental Program}

Five large scale $(3000 \times 3000 \times 60 \mathrm{~mm})$ RC flat slabs supported by nine columns $(100 \times 100 \times 310 \mathrm{~mm})$ and divided into four square panels $(1500 \times 1500 \mathrm{~mm})$, as shown in Fig. 1, were loaded gradually in sixteen points up to failure to investigate the effects of both the openings geometry; size and location, and CFRP strengthening of slabs with openings. One of these slabs (S1) was a control one without openings and strengthening. The second slab (S2) had two symmetric openings $(400 \times 400 \mathrm{~mm})$ at the intersection of field and column strips, while the third slab (S4) had one column-face opening $(200 \times 200 \mathrm{~mm})$ at the intersection of column strips. Openings size was chosen larger than that recommended by the Egyptian code ECP203[11]. The last two slabs, S3 and S5 were similar to S2 and S4, respectively, but with CFRP sheets strengthening, as shown in Fig. 2. Figure 1, also, shows the locations of four LVDT's and two electrical strain gauges, while Fig. 3 shows the instrumentation and test setup. As shown in Fig. 3 , the loading frame was designed in such a way that the lower steel boxes used to transmit the loading from the cell to the slabs will cause the loading to affect through sixteen points which is required to simulate the uniformly distributed loadings as close as possible. The average cube strength for the concrete of the all slabs was $40 \mathrm{MPa}$. The designed reinforcement ratio was $0.33 \%$, of steel with $280 \mathrm{MPa}$ yielding stress, as 6 bars $\varnothing 6 \mathrm{~mm} / \mathrm{m}$ in the two directions as lower reinforcement. The upper reinforcement, with the previous ratio, was only placed above the columns; at the central column covering an area of $1 \times 1 \mathrm{~m}$ and at other columns covering an area of $0.4 \times 0.4 \mathrm{~m}$. Figure 4 shows the reinforcement of the tested slabs and their supporting columns. Finally, Table I shows the mechanical properties of the used CFRP sheets.
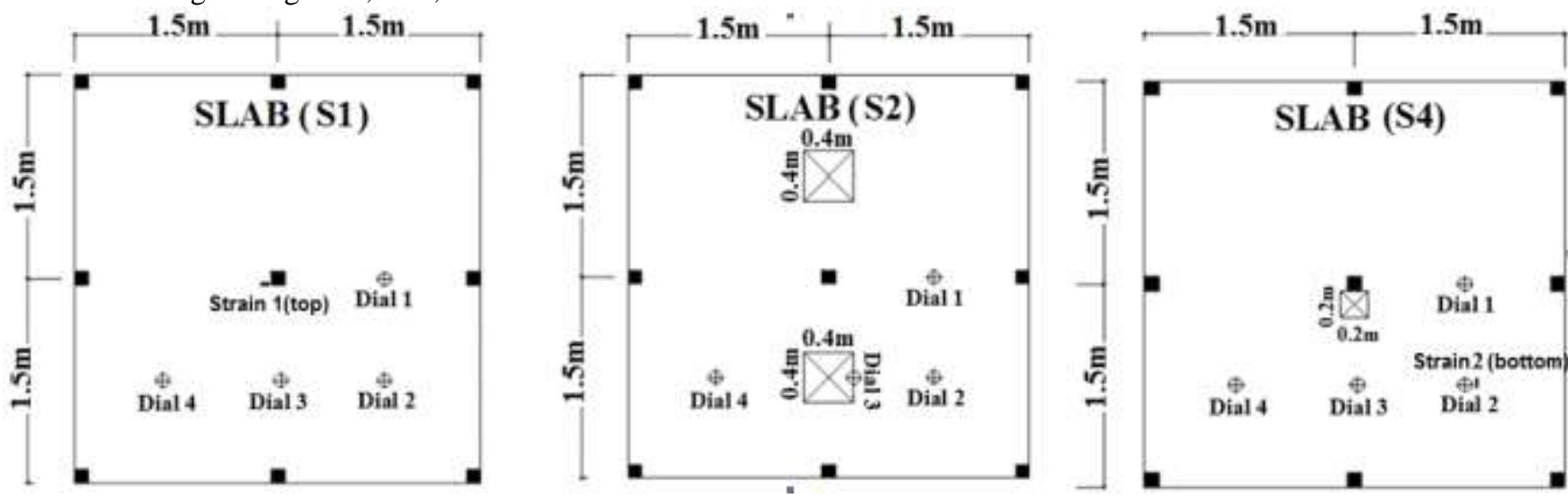

Figure 1. Dimensions of Slabs and Locations of Openings and Dial Gauges.
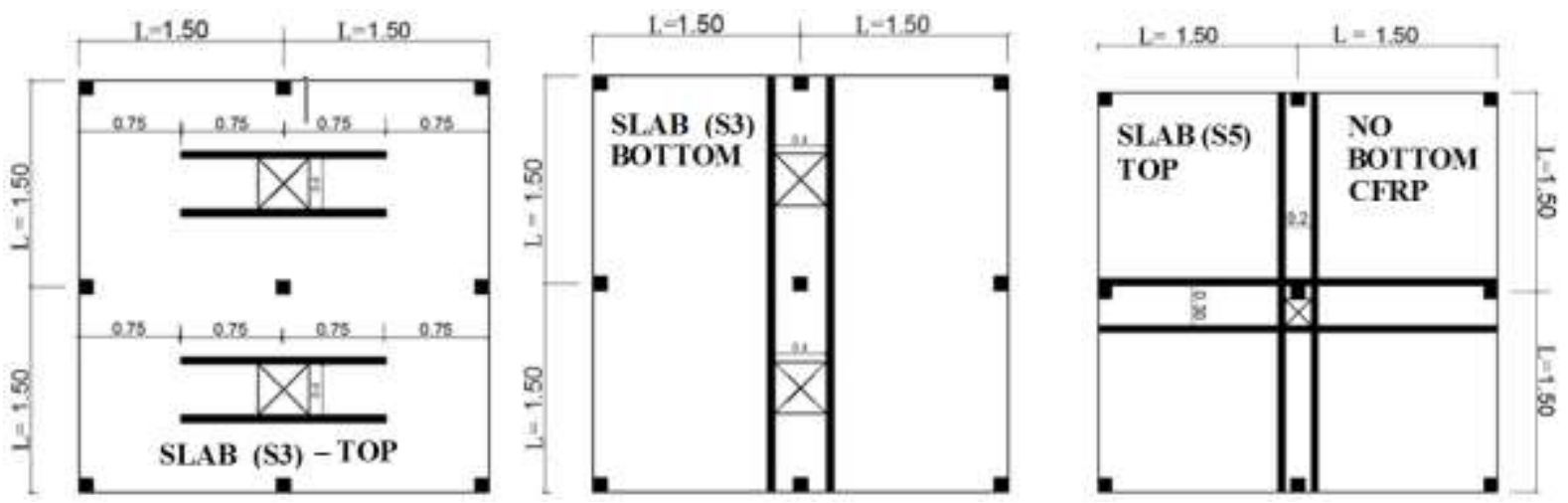

Figure 2. Locations and Dimensions of CFRP strengthening Sheets.
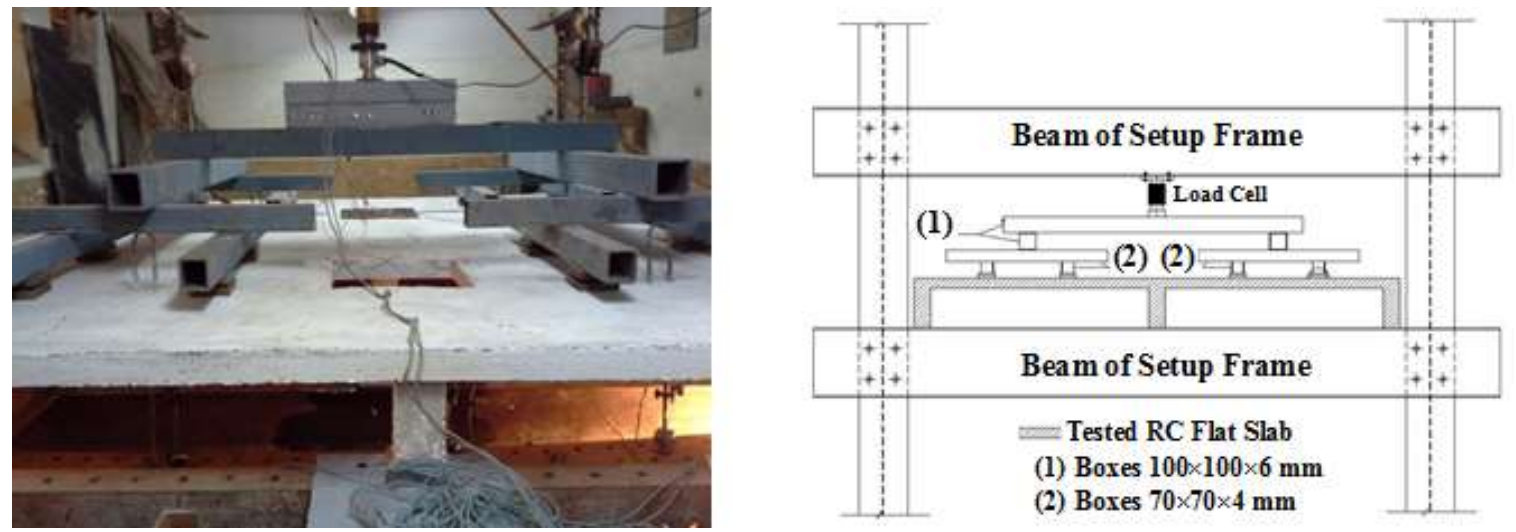

Figure 3. Test Setup. 
Proc. of the Fifth International Conference on Advances in Civil, Structural and Environmental Engineering - ACSEE 2017. Copyright ( ) Institute of Research Engineers and Doctors. All rights reserved.

ISBN: 978-1-63248-122-1 doi: 10.15224/ 978-1-63248-122-1-31

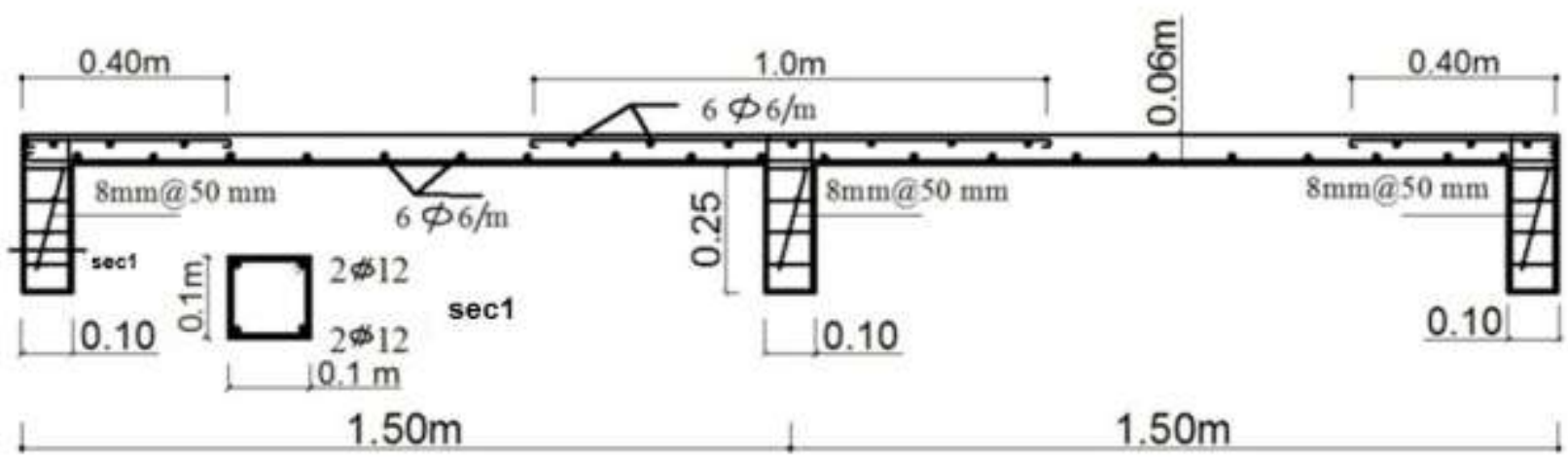

Figure 4. Upper and Lower Reinforcement.

Table I. Mechanical Properties of CFRP Sheets.

\begin{tabular}{|c|c|c|c|c|}
\hline $\begin{array}{c}\text { Width } \\
(\mathrm{mm})\end{array}$ & $\begin{array}{c}\text { Thickness } \\
(\mathrm{mm})\end{array}$ & $\begin{array}{c}\text { Tensile } \\
\text { Strength } \\
(\mathrm{MPa})\end{array}$ & $\begin{array}{c}\text { Ultimate } \\
\text { Strain }\end{array}$ & $\begin{array}{c}\text { Elasticity } \\
\text { Modulus } \\
(\mathrm{GPa})\end{array}$ \\
\hline 50 & 1.2 & 2700 & 0.014 & 165 \\
\hline
\end{tabular}

\section{Results and Discussions}

\section{A. Cracking Patterns and Failure loads}

All the tested slabs failed in flexure except slab S5 which failed due to punching shear around central column. The following observations were noted during testing of the slabs

Slab S1: Fig. 5 shows crack patterns at failure load of both top and bottom surfaces. Under loading, fine flexural cracks were observed at top surface due to negative moments around all columns at a load of $110 \mathrm{kN}$. Under the same load, bottom flexural cracks started to appear at the location of maximum positive moments in column strips. Also, some torsional cracks appeared near edge and corner columns due to torsional moments. At a load of $115 \mathrm{kN}$ the top central crack extended longitudinally and propagated towards edge columns in the two orthogonal main directions and dividing the slab to four parts. Each part behaved like a slab supported on four columns and that led to increased numbers of bottom flexural cracks under the applied loads. These bottom cracks extended longitudinally and propagated toward the edges of the slab at $120 \mathrm{kN}$. Crushing of concrete in compression occurred at a load $\mathrm{P}_{\mathrm{u}}=130 \mathrm{kN}$ at bottom surface (along the two orthogonal lines connecting the edge columns and passing through the central column) and also at some locations on top surface (mid span of edge column strip and mid span of central column strip).
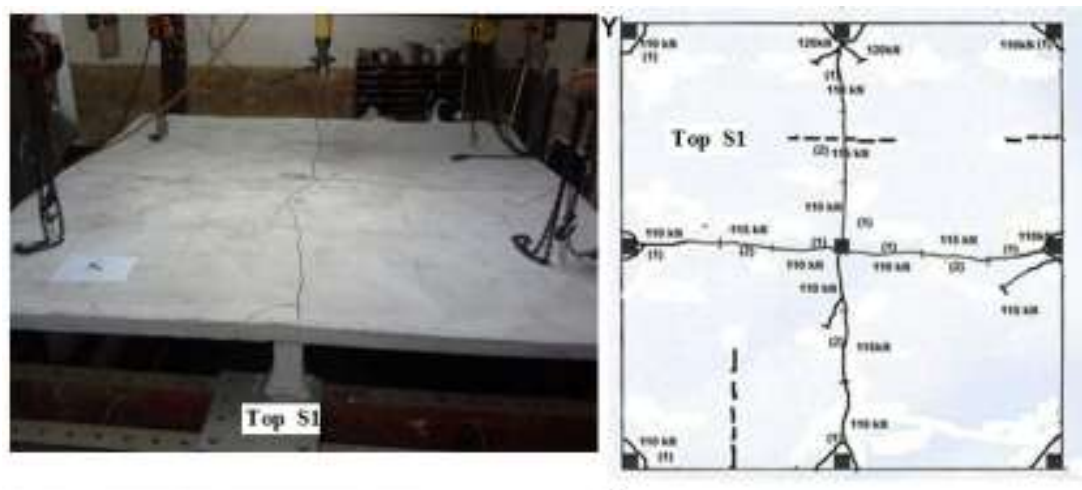

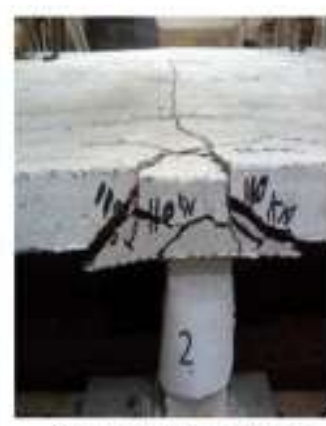

Flexural Torsional Cracks near Edge Colume
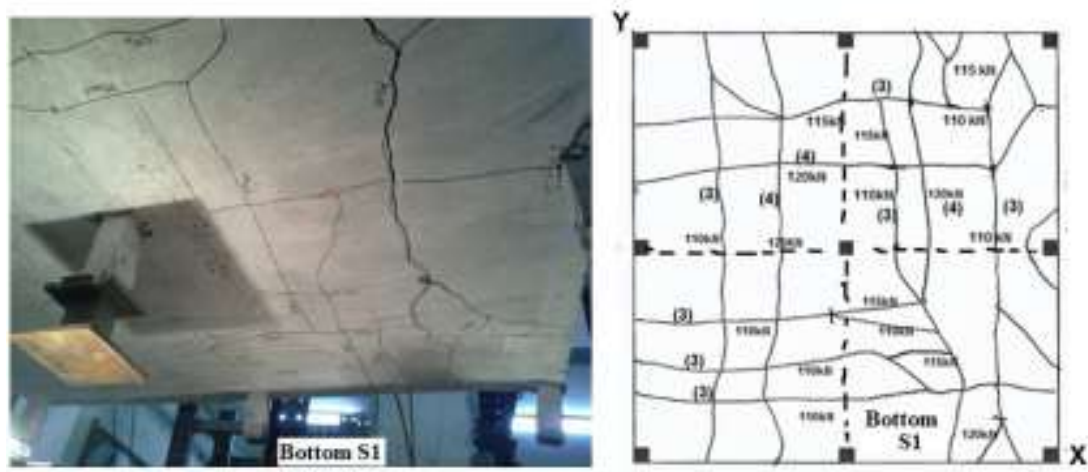
$x$

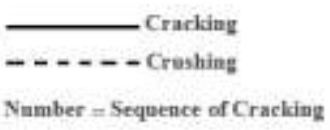

Figure 5. Crack Patterns of Control Flat Slab S1. 
Proc. of the Fifth International Conference on Advances in Civil, Structural and Environmental Engineering - ACSEE 2017. Copyright (C) Institute of Research Engineers and Doctors. All rights reserved.

ISBN: 978-1-63248-122-1 doi: 10.15224/ 978-1-63248-122-1-31

Slab S2: Fig. 6 shows crack patterns at failure load of both top and bottom surfaces. Longitudinal flexural cracks appeared first at top surface of slab at a load of $75 \mathrm{kN}$ (about $75 \%$ of $P_{u}$ and about $68 \%$ of $P_{c r}$ of S1) along the line connecting the two openings passing through the central column. At a load of $80 \mathrm{kN}$ (about $80 \%$ of $P_{u}$ ) top cracks appeared in the other direction starting from central column and also cracks appeared around the edge and corner columns. Also, at this load level, bottom cracks started from opening corners and edges and extended normal to line connecting the two openings. At a load of $85 \mathrm{kN}$ the top flexural cracks extended longitudinally and propagated towards edge columns in $\mathrm{x}$ direction. Under the same load $(85 \mathrm{kN})$, bottom longitudinal cracks occurred at center of each span in the direction of the two openings (at position of maximum positive moments in $\mathrm{x}$ direction) and extended the full width of the slab. Figure 6 shows that cracks occurred at the inner surface of opening. These cracks started as extension of bottom cracks observed around edges and propagated towards the top surface of slab. Flexural failure occurred by crushing of concrete in compression at a load of $97 \mathrm{kN}$. Crushing occurred at bottom surface along the line connecting the two opening and passing through the central column.
At the same load, crushing occurred at top surface at some locations (mid span of edge column strip and mid span of central column strip normal to opening line).

Slab S4: Fig. 7 shows crack patterns at failure load of both top and bottom surfaces. At a load of $50 \mathrm{kN}$ (about $50 \%$ of $P_{u}$ ) a longitudinal flexural crack occurred suddenly on the bottom surface at one side of the slab (crack number1) starting normal to location of positive moment of the column strip containing the opening (parallel to y direction) and extended to the slab edge at a load of $70 \mathrm{kN}$. The early appearance of these cracks may be due to increasing of positive moment at column strip in $\mathrm{x}$ direction as results of the redistribution of moments next to opening. At top surface, cracks appeared at a load of 80 $\mathrm{kN}$ starting from the central column towards edge columns in $\mathrm{x}$ and $\mathrm{y}$ directions. At a load equal $84 \mathrm{kN}$, top flexural cracks appeared around edge columns. Under the same load $(84 \mathrm{kN})$, another top crack propagated longitudinally from edge column toward opening corner. The ultimate failure load was equal to $100 \mathrm{kN}$. The failure was flexure failure followed by punching shear failure around central column.
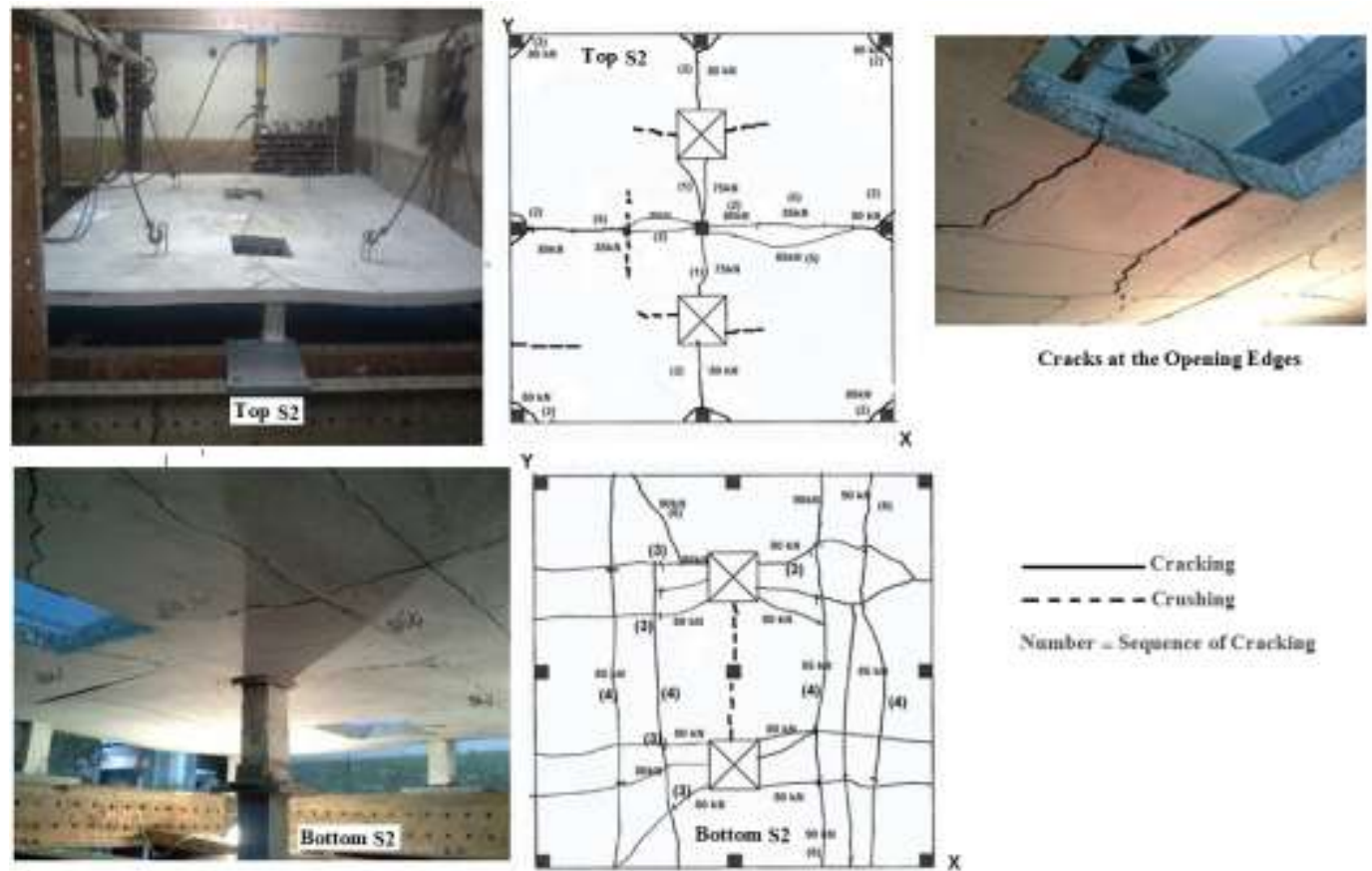

Figure 6. Crack Patterns of Opened Flat Slab S2.
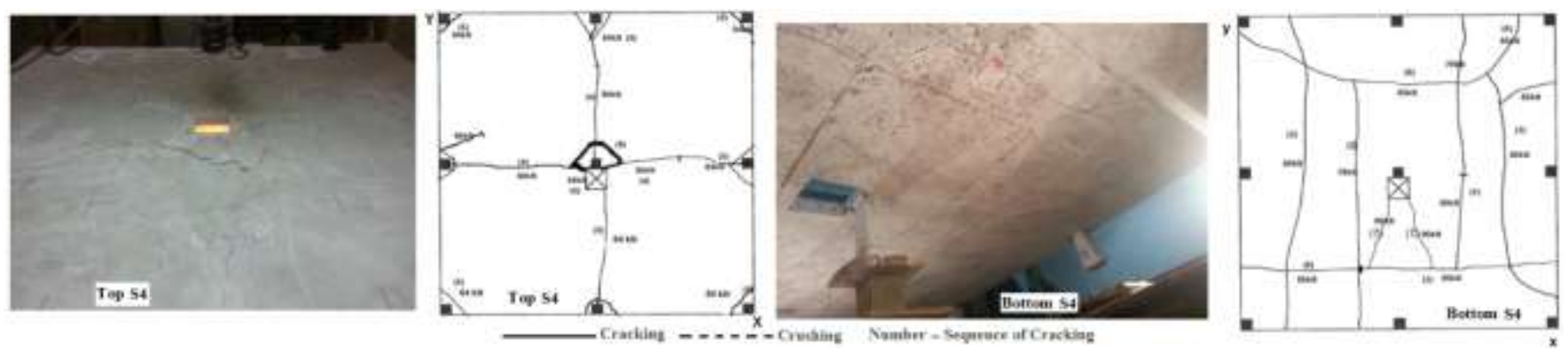

Figure 7. Crack Patterns of Opened Flat Slab S4. 
Proc. of the Fifth International Conference on Advances in Civil, Structural and Environmental Engineering - ACSEE 2017. Copyright (C) Institute of Research Engineers and Doctors. All rights reserved.

ISBN: 978-1-63248-122-1 doi: 10.15224/ 978-1-63248-122-1-31

Slab S3: Fig. 8 shows crack patterns at failure load of both top and bottom surfaces. Crack pattern for this slab (S3) was similar to that for the unstrengthened slab (S2) except that no cracks were observed at the inside sides of opening for the strengthened slab. This indicates that strengthening of slabs enhanced the strength and increased the cracking load but with similar crack pattern at both top and bottom surfaces. At a load of $110 \mathrm{kN}$ (about $85 \%$ of $P_{u}$ ) debonding of CFRP strips attached to top surface occurred. This may be due to insufficient development length of CFRP. Failure occurred at a load of $130 \mathrm{kN}$ by crushing of concrete in compression. Crushing occurred at bottom surface along the full width of the line connecting the two opening and passing through the central column. At the same load, crushing occurred at top surface at mid span of edge column strip and mid span of central column strip normal to CFRP strips). No crushing occurred at mid span of middle column strip at openings although it was occurred at unstrengthened slab (S2) and solid slab (S1).
Slab S5: Fig. 9 shows crack patterns at failure load of both top and bottom surfaces. As mentioned for slab S4 (similar to S5 but without strengthening), early cracking of bottom surface appeared at load of $70 \mathrm{kN}$ (about $56 \%$ of $P_{u}$ and about $63 \%$ of $P_{c r}$ of S1) and extended to the full width of the slab along the line of mid span of both column and field strips. Also, parallel bottom cracks appeared at load of $85 \mathrm{kN}$ and $105 \mathrm{kN}$. At top surface, the same pattern of cracks as S4 appeared, i.e. two orthogonal cracks along the center of middle column strips, in addition to top cracks around edge and corner columns. Punching shear failure at central column occurred suddenly at a load of $124 \mathrm{kN}$ (about $95 \%$ of $P_{u}$ of S1) with the formation of pyramidal plug, due to insufficient punching shear strength. No yield was recorded in top and bottom longitudinal reinforcement.
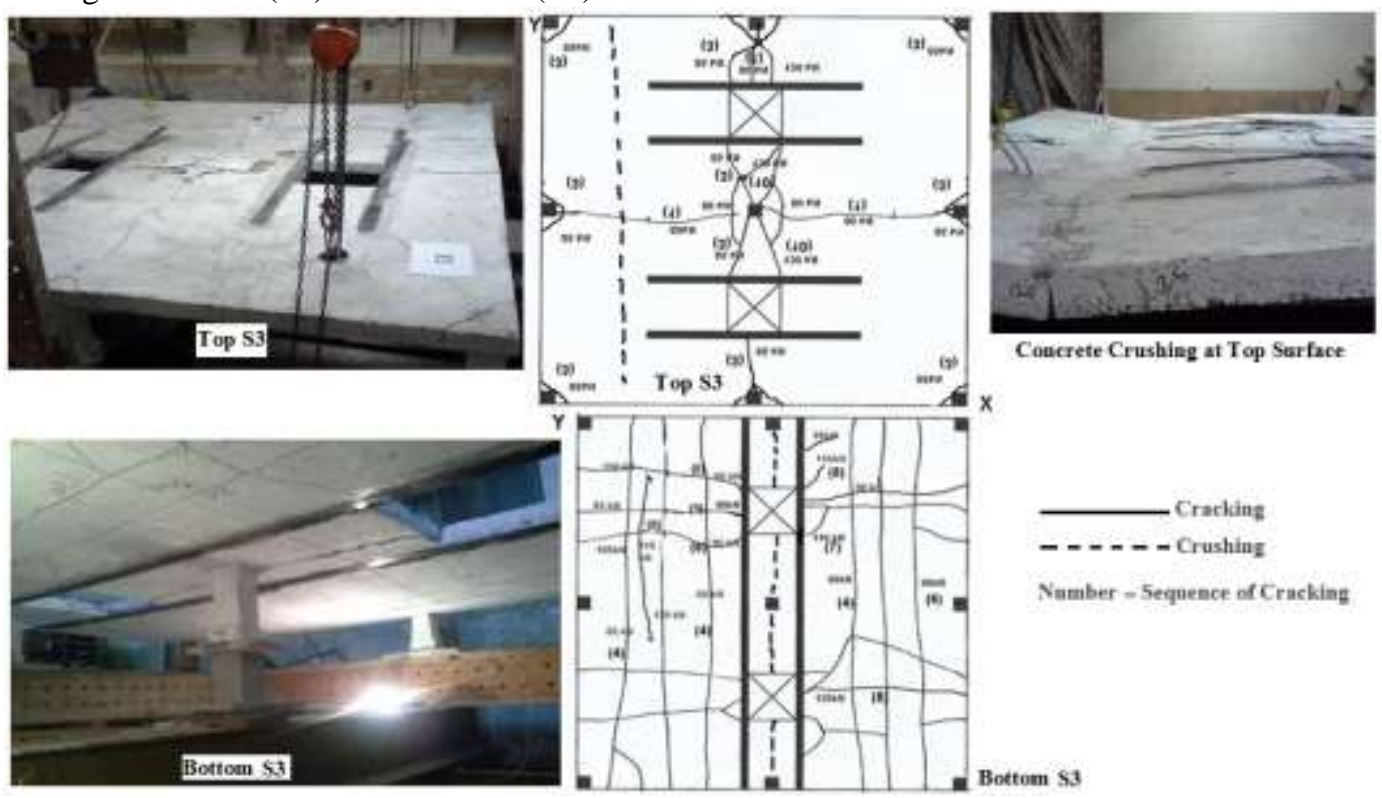

Coucrete Crushing at Top Sarface
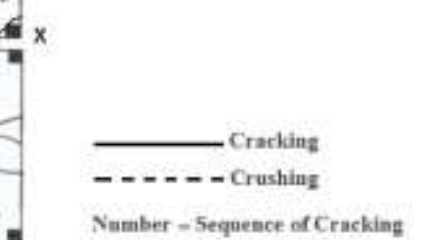

Figure 8. Crack Patterns of Opened and Strengthened Flat Slab S3.
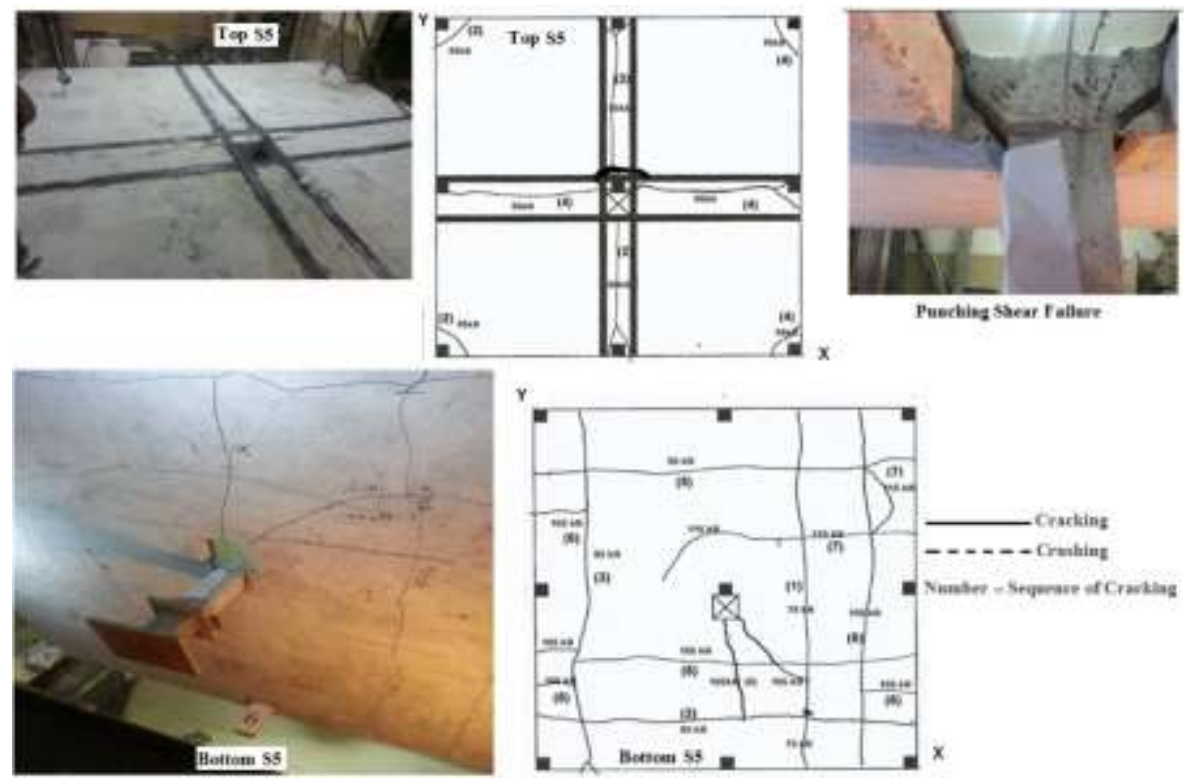

Figure 9. Crack Patterns of Opened and Strengthened Flat Slab S5. 
Proc. of the Fifth International Conference on Advances in Civil, Structural and Environmental Engineering - ACSEE 2017. Copyright (@) Institute of Research Engineers and Doctors. All rights reserved.

ISBN: 978-1-63248-122-1 doi: 10.15224/ 978-1-63248-122-1-31

\section{B. Deflections, Ductility and Toughness}

Figure 10 shows the load-deflection curves at the locations of the dial gauges, shown in Fig.1. These results are tabulated in Tables II and III as follows. Table II shows the values of cracking load $\left(P_{c r}\right)$, failure load $\left(P_{u}\right)$, reinforcement yield load $\left(P_{y}\right)$ and modes of failure.

Table III shows the values of deflections at cracking load $\left(\Delta_{\mathrm{cr}}\right)$ and at failure $\left(\Delta_{\mathrm{u}}\right)$, ductility factor $\left(\left(\Delta_{\mathrm{u}} / \Delta_{\mathrm{cr}}\right)\right.$ and toughness (the area under the load-deflection curves), while $\Delta_{\mathrm{cr}}$ and $\Delta_{\mathrm{u}}$ are measured at the intersection of two field strips (dial 4).

Table II. Measured Results of Loads and Modes of Failure.

\begin{tabular}{|c|c|c|c|c|c|c|c|c|c|c|}
\hline \multirow{2}{*}{ Specimen } & \multirow[b]{2}{*}{$\begin{array}{c}\boldsymbol{f}_{c u} \\
(\mathbf{M P a})\end{array}$} & \multicolumn{2}{|c|}{$P_{c r}(\mathrm{kN})$} & \multicolumn{2}{|c|}{$P_{y}(\mathrm{kN})$} & \multirow{2}{*}{$\begin{array}{c}P_{u} \\
(\mathbf{k N})\end{array}$} & \multirow[b]{2}{*}{$\boldsymbol{P}_{c r} / \boldsymbol{P}_{u}$} & \multirow[b]{2}{*}{$P_{y} / P_{u}$} & \multirow[b]{2}{*}{$\left(\frac{P_{u}}{P_{u(S 1)}}\right) \%$} & \multirow[b]{2}{*}{ Failure Mode } \\
\hline & & Top & Bottom & Top & Bottom & & & & & \\
\hline S1 & 40 & 110 & 110 & 120 & 120 & 130 & 0.84 & 0.92 & ---- & Flexure \\
\hline S2 & 38 & 75 & 80 & 81 & NY & 97 & 0.77 & 0.83 & 74.6 & Flexure \\
\hline S3 & 42 & 85 & 85 & 96 & 103 & 130 & 0.65 & 0.74 & 100 & Flexure \\
\hline S4 & 40 & 80 & 50 & At Failure & 85 & 100 & 0.50 & 0.85 & 76.9 & Flexure Followed by Punching \\
\hline S5 & 40 & 85 & 70 & NY & NY & 124 & 0.56 & NY & 95 & Punching Shear \\
\hline
\end{tabular}

Table III. Measured Results of Deflections and Toughness at Dial-4.

\begin{tabular}{|c|c|c|c|c|c|c|}
\hline Specimen & $\begin{array}{c}\Delta_{\boldsymbol{c r}} \\
(\mathbf{m m})\end{array}$ & $\begin{array}{c}\Delta_{\boldsymbol{u}} \\
(\mathbf{m m})\end{array}$ & $\Delta_{\boldsymbol{u}} / \Delta_{\boldsymbol{c r}}$ & $\begin{array}{c}\text { Toughness } \\
(\mathbf{K N . m m})\end{array}$ & $\begin{array}{c}\text { \% of Ductility } \\
\text { Decreasing } \\
\text { Relative to S1 }\end{array}$ & $\begin{array}{c}\text { \% of Toughness } \\
\text { Decreasing } \\
\text { Relative to S1 }\end{array}$ \\
\hline S1 & 3.8 & 54.2 & 14.3 & 6100 & ---- & ---- \\
\hline S2 & 3.5 & 44.3 & 12.6 & 3800 & 11.88 & 37.70 \\
\hline S3 & 2.8 & 22.3 & 8.0 & 2180 & 44.06 & 64.26 \\
\hline S4 & 1.8 & 17.7 & 10.0 & 1360 & 30.07 & 77.70 \\
\hline S5 & 1.5 & 13.4 & 9.0 & 1175 & 37.06 & 80.74 \\
\hline
\end{tabular}
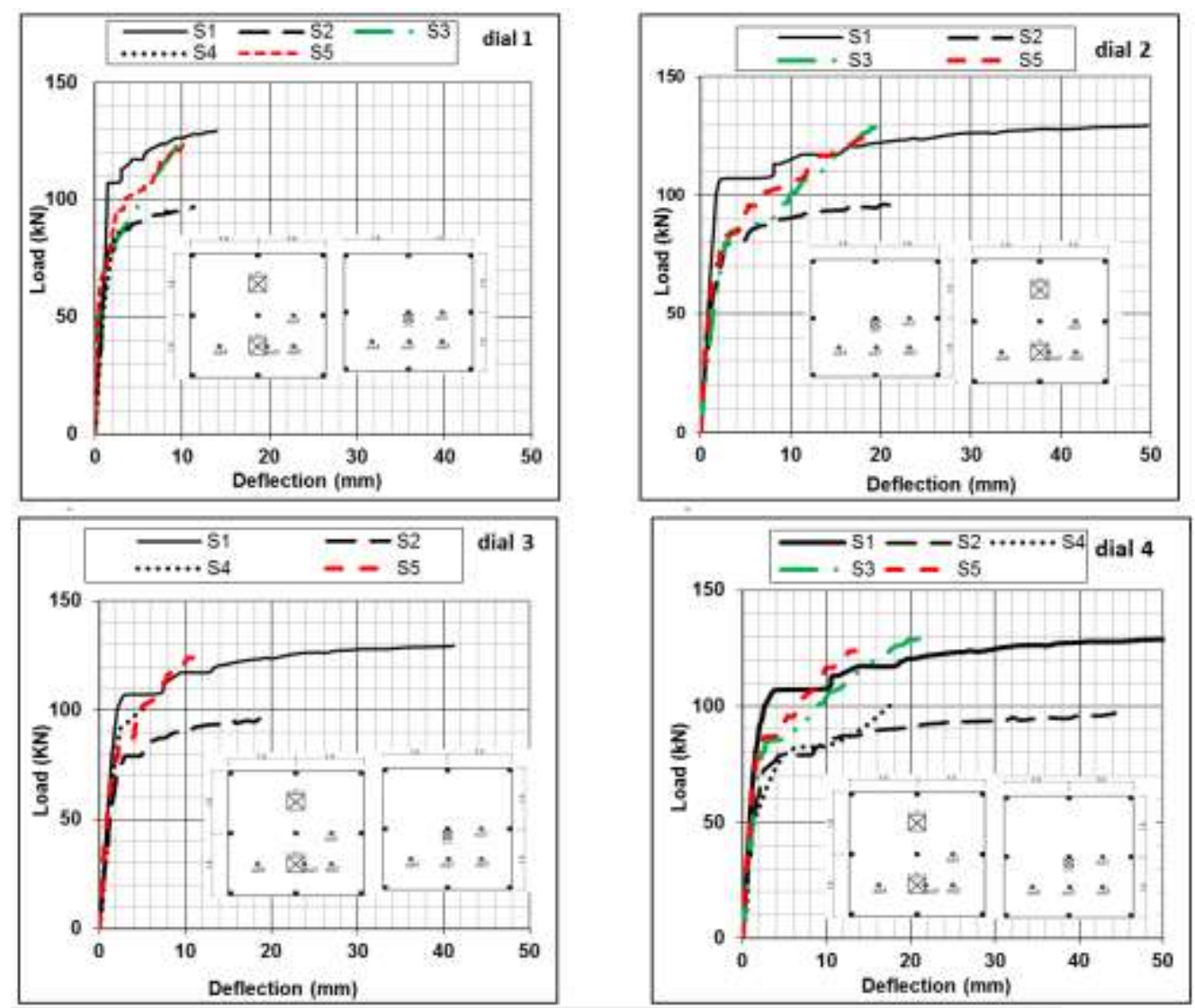

Figure 10. Load-Deflection Curves for Tested Slabs at two Locations. 
Proc. of the Fifth International Conference on Advances in Civil, Structural and Environmental Engineering - ACSEE 2017. Copyright (C) Institute of Research Engineers and Doctors. All rights reserved.

ISBN: 978-1-63248-122-1 doi: 10.15224/ 978-1-63248-122-1-31

From the results given in Table III and Figure 10 the following can generally be observed:

1- For slab S1 (without opening), very large values of deflection were recorded after cracking with small increase in the applied load. The maximum recorded deflection at failure $\Delta_{\mathrm{u}}=54.2 \mathrm{~mm}\left(=0.9 \mathrm{t}_{\mathrm{s}}=\mathrm{L} / 27.7\right.$, where $\left(t_{s}\right)$ is the slab thickness and $(L)$ is the span of the slab).

2- Similar behavior was obtained for slab S2, provided with two openings along middle column strip, but with less values of maximum deflection at failure. Strengthening this slab (i.e. slab S3) showed stiffer behavior at all locations, with a reduction in the deflection values, at failure, by about $50 \%$.

3- For slab S4, provided with an opening close to the middle column, the maximum deflection at failure was about $33 \%$ of that for the solid reference slab (S1) at same location ( $\mathrm{F} / \mathrm{F}$ intersection, i.e. intersection of field strips). Strengthening this slab (i.e. slab S5) showed stiffer behavior at all locations compared with the unstrengthened one, with a reduction of maximum deflection by $25 \%$ and by $75 \%$ when compared with the solid (reference) slab.

4- The maximum value of $\left(\Delta_{\mathrm{u}} / \Delta_{\mathrm{cr}}\right)$ was 14.3 for the solid (reference) slab S1. The presence of two openings at middle column strip (Slab S2) did not affect this ratio and ductile behavior was observed for this slab, while when opening was located adjacent to central column (Slab S4) this value decreased by about $30 \%$. However, for the strengthened slabs; S3 and S5, less ductile behavior was observed and the ratio $\left(\Delta_{\mathrm{u}} / \Delta_{\mathrm{cr}}\right)$ reduced to 8.0 and 9.0 for S3 and S5, respectively. Another measure of ductility is the calculated values of toughness (the area under the loaddeflection relationship) for each specimen; these values are given in Table III. The maximum value of toughness was calculated for the solid (reference) slab S1. Toughness for slabs with openings ( $\mathrm{S} 2$ and $\mathrm{S} 4$ ) was reduced by about $38 \%$ for $\mathrm{S} 2$ and $77 \%$ for S4. When slab S2 was strengthened by CFRP strips (i.e. S3), the toughness (and hence the ductility) reduced by about $65 \%$ when compared with the (reference) slab S1. On the other hand, slab S4 when strengthened by CFRP (i.e. S5), the toughness reduced by about $80 \%$.

\section{Reinforcement Steel strain}

Figure11 shows the change of strains in steel reinforcement with loading till failure. The measurements of two strain gauges are used; Strain 1 at the top surface and Strain 2 at the bottom surface in the locations shown in Fig. 1. According to these results and those mentioned in the previous sections, it can be concluded that:

1- The presence of an opening located at edge of central column affected greatly the negative moment over the column. As shown in Fig. 11, yield in tension occurred at the positive moment locations at about $85 \%$ of $\mathrm{P}_{\mathrm{u}}$. Also, yield was recorded for top steel over the central column in a direction normal to that of opening line; strain gauge No. 1. Strengthening slab S4 (i.e. slab S5) by CFRP strps resulted in an increase in the slab strength and no yield was recorded up to failure at the measured five locations

2- The Difference in steel strain which located at bottom reinforcement (strain 2) between slabs S2 and S3 for the same loading is very small, while this difference between slabs S4 and S5 is large. This insures the capability of the CFRP strengthening to enhance the behavior of the flat slabs opened in the column-column strips, especially adjacent to the central columns.
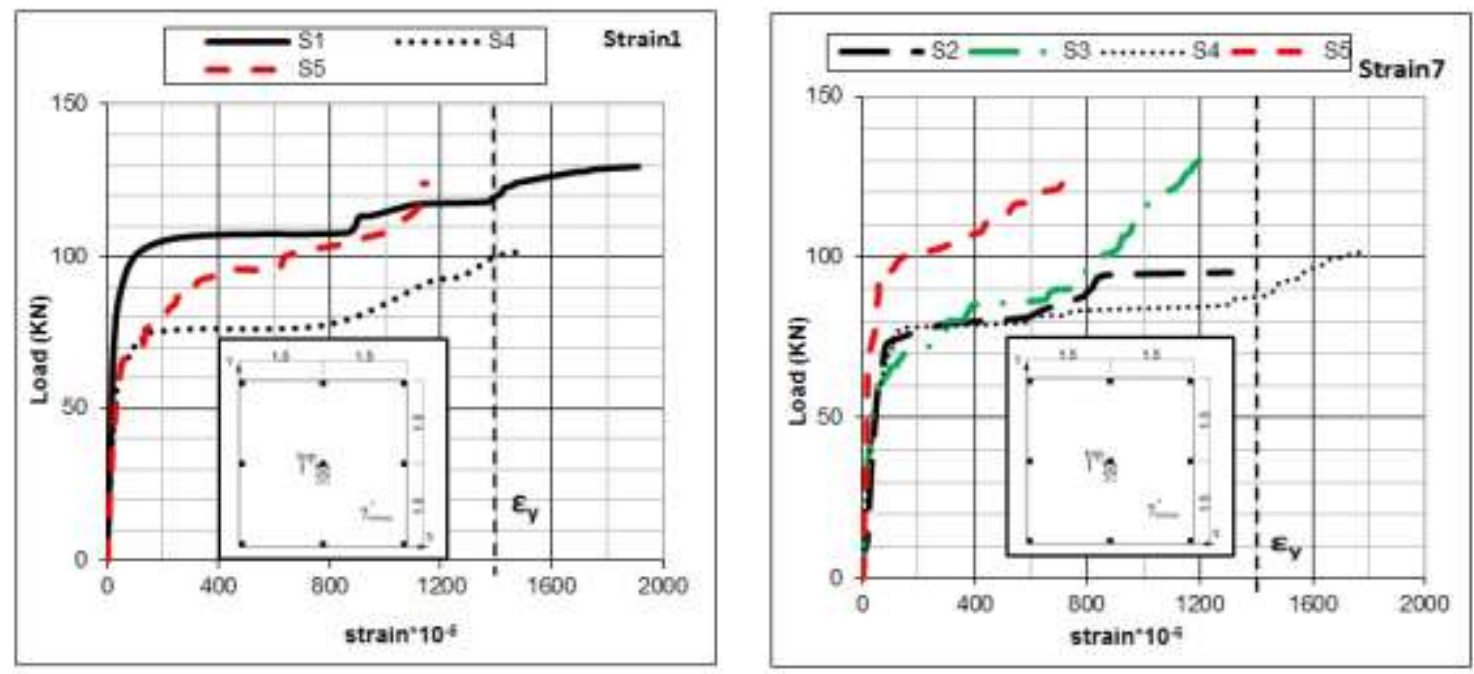

Figure 11. Load- Steel Strain Curves for Tested Slabs at Two locations 
Proc. of the Fifth International Conference on Advances in Civil, Structural and Environmental Engineering - ACSEE 2017. Copyright (C) Institute of Research Engineers and Doctors. All rights reserved.

ISBN: 978-1-63248-122-1 doi: 10.15224/ 978-1-63248-122-1-31

\section{Conclusions}

The Objective of this paper is to investigate the effect of presence of openings in continuous flat slabs and to check if the CFRP strengthening of such opened flat slabs will enhance their behavior. An experimental program was conducted using five large scale flat slabs and the following were concluded:

1- Failure loads of opened strengthened slabs S3 and S5 are equal or very close to that of the solid slab S1. This means that CFRP strengthening of opened slabs enhanced the ultimate load by $25-30 \%$. However, their maximum deflections are less than those of the opened unstrengthened slabs S2 and S4.

2- The presence of two openings at middle column strip (Slab S2) did not affect the ductility. On the other hand, locating the opening adjacent to central column (Slab S4) decreased the ductility by about $30 \%$.

3- The presence of two openings at middle column strip caused a reduction in the first cracking load by about $31 \%$ compared to the solid slab S1. However, about $55 \%$ reduction in the first cracking load was recorded in the slab provided with one opening located at the central column edge. On the other hand, CFRP strengthening showed slight effect on increasing of the top and bottom first crack load.

4- The crack pattern at failure for all slabs was approximately similar. This pattern was characterized by the occurrence of two top perpendicular cracks along the slab passing through the middle column and a mesh of bottom cracks in the two directions around the central column.

5- Debonding of CFRP strips attached to top surface occurred for slab which was strengthened around the two openings at the intersection of column/ field strip. This debonding initiated at a load of $\left(85 \% P_{u}\right)$ at a corner of the opening where the maximum negative moment occurred. This debonding occurred due to insufficient development length of CFRP laminates in spite of its length was half the span length.

6- The failure mode of slab with openings located at the intersection of column / field strips was classified as flexural ductile failure and this mode did not change when this slab was strengthened with CFRP. On the other hand, the failure mode of slab with opening next to central column was flexural followed by punching failure and this mode changed to sudden punching failure when the slab was strengthened with CFRP.

7- Strengthening flat slab with two opening at middle column reduce the crack at the inside face of the openings.

\section{References}

[1] American Concrete Institute, ACI 318 Building Code Requirements for Structure Concrete and Commentary, 2014.

[2] Canadian Standards Association, "Design of Concrete Structures for Buildings", CAN3, A23.3-M94, Rexdale, Ontario, Canada, 1984.

[3] AS 3600, “Australian Standard for Concrete Structures," Standard Association of Australia, North Sydney, Australia, (1994), 155 pp.
[4] Ibrahim, W.W., "Behavior of Flat Plates with Openings", Ph.D. Thesis, Zagazig University, 1994.

[5] Tayel, M., Soliman, M, and Ibrahim, K., "Experimental Behavior of Flat Slabs with Openings under Effect of Concentrated Loads", Alexandria Engineering Journal, Vol. 43, No.2, pp. 203- 214, 2004.

[6] G. Sheetal and Itti, S.V., "Study on Two Way RC slab Using ANSYS with \& without Central Opening", International Journal of Scientific Engineering \& Technology, Vol. 3, Issue no. 8, pp. 1108-1110, 2014.

[7] Tanu, Kaur, I., and Singh, Y., "Finite Element Analysis of RC Slab with or without Opening Strengthened with FRP Wraps", International Journal of Computer Applications, 2016.

[8] Rashied, S. M., "Punching Shear Resistance of Flat Slabs with Openings", International journal of civil Engineering \& Technology (IJCIET), 2015.

[9] Enochsson, O., Lundqvist, J.,Bjo“rn Ta“ljsten ,Piotr Rusinowski ,and Thomas Olofsson., "CFRP Strengthened Openings in Two-Way Concrete Slabs - An Experimental and Numerical Study", Construction and Building Materials Journal, 2007, Vol. 21, pp.810-826.

[10] Tan, K., "Strengthening of Flat Plates with an Opening Using FRP Systems", Asia-Pacific Conference on FRP in Structures, Hokkaido University, 2012.

[11] Housing and Building Research Center (HBRC), "ECP-203: Egyptian Code of Practice for the Design and Implementation of Reinforced Concrete Structures", Cairo, Egypt, 2007.

[12] Ibraheem, M. S, "Strengthening of Continuous Flat Slabs with Openings by Using CFRP Laminates", Ph.D Thesis, in Progress, University of Alexandria, Egypt, 2017. 